\title{
Decreased serum ferritin and vitamin D levels in patients with recurrent aphthous stomatitis
}

\author{
Funda Tamer ${ }^{1}$, Emine Avcl ${ }^{2}$
}

${ }^{1}$ Ufuk University School of Medicine, Department of Dermatology, Ankara, Turkey, ${ }^{2}$ General Directorate of Public Health, Department of Infectious Diseases, Ankara, Turkey

Corresponding author: Dr. Funda Tamer, E-mail: fundatmr@yahoo.com

\begin{abstract}
Background: Recurrent aphthous stomatitis is the most common ulcerative disease of the oral mucosa. Several predisposing factors like oral microbial flora, stress, viral infections, vitamin and mineral deficiencies have been associated with the disease. However, the etiopathogenesis of recurrent aphthous stomatitis remains unknown. Material and Methods: The study included 20 patients with recurrent aphthous stomatitis and 20 healthy individuals within the control group. Complete blood count, serum levels of ferritin, folate, vitamin $\mathrm{B}_{12}$, zinc, 25-hydroxyvitamin $\mathrm{D}$, herpes simplex virus type-l IgG and herpes simplex virus type-2 IgG were evaluated in each participant. Results: White blood cell count, platelet count, mean platelet volume, mean serum levels of hemoglobin, folate, vitamin $B_{12}$ and zinc were statistically similar in patients and healthy individuals. However, the mean serum ferritin level was significantly lower in patients $(26.5 \pm 25.5 \mathrm{ng} / \mathrm{mL})$ compared to healthy individuals $(42 \pm 30 \mathrm{ng} / \mathrm{mL})(\mathrm{p}=0.04)$. The mean serum 25-hydroxyvitamin $\mathrm{D}$ level was significantly lower in patients $(13.6 \pm 6.5 \mathrm{ng} / \mathrm{mL})$ compared to healthy individuals $(20.9 \pm 10 \mathrm{ng} / \mathrm{mL})(\mathrm{p}=0.01)$. No significant difference has been observed between two groups in the frequency of positive serum herpes simplex virus type-l IgG and herpes simplex virus type-2 IgG levels. Conclusions: No association has been observed between recurrent aphthous stomatitis and white blood cell count, mean platelet volume, serum levels of hemoglobin, folate, vitamin $\mathrm{B}_{12}$, zinc, herpes simplex virus type-1 IgG and herpes simplex virus type-2 IgG. However, decreased serum levels of ferritin and 25-hydroxyvitamin $\mathrm{D}$ were more prevalent in patients with recurrent aphthous stomatitis compared to healthy individuals.
\end{abstract}

Key words: Aphthous; Ferritin; Recurrent; Stomatitis; Vitamin D

\section{INTRODUCTION}

Recurrent aphthous stomatitis is the most common inflammatory disease of the oral mucosa. It is characterized by painful round ulcers with pseudomembranous center and erythematous borders $[1,2]$. The prevalence of the disease is $0.5 \%$ to $75 \%$ all over the world. Recurrent aphthous stomatitis is more common in women than in men. The ulcers usually begin during the second decade of life [1]. Recurrent aphthous stomatitis is classified into three clinical types; minor, major, and herpetiform ulcers [2]. Most of the patients (>85\%) with recurrent aphthous stomatitis present with minor ulcers that have a diameter less than $1 \mathrm{~cm}$ [2]. Major ulcers (Sutton's disease) have a diameter greater than $1 \mathrm{~cm}$ and they can persist for weeks $[2,3]$. Herpetiform type presents as multiple, small ulcers with $1-2 \mathrm{~mm}$ in size, that may heal with scarring [1].

The etiopathogenesis of recurrent aphthous stomatitis remains unknown. However, several predisposing factors have been associated with the disease. Genetic predisposition, iron, vitamin $\mathrm{B}_{12}$ and folic acid deficiencies, nonsteroidal antiinflammatory drugs, angiotensin converting enzyme inhibitors, gluten sensitive enteropathy, inflammatory bowel disease, stress, trauma to oral mucosa like dental procedures, Helicobacter pylori and viral infections have been implicated in the development of recurrent aphthous stomatitis [4].

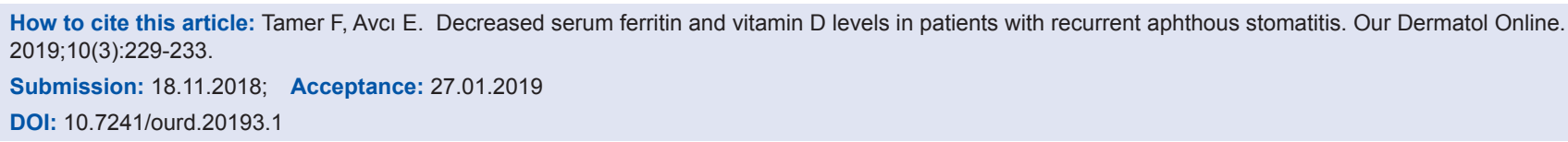


The differential diagnosis should include chickenpox, erythema multiforme, erosive lichen planus, RigaFede disease, pemphigus vulgaris and pemphigoid [5]. Treatment of recurrent aphthous stomatitis can be difficult particularly in severe cases [6]. It is crucial to rule out an underlying systemic disorder in the management of disease. However, most of the patients are healthy except for painful oral ulcers [7]. Topical therapies include chlorhexidine rinse, antibiotics like doxycycline and minocyclin, diclofenac, benzocaine, lidocaine and corticosteroids. Furthermore, penicillin $\mathrm{G}$, rifampin, dapsone, zinc, pentoxifylline, thalidomide, colchicine and ascorbic acid have been used in the management of recurrent aphthous stomatitis [6].

\section{MATERIALS AND METHODS}

The study included 20 patients with recurrent aphthous stomatitis and 20 healthy individuals within the control group. Medical records of the participants were reviewed retrospectively between January 2018 and September 2018. Laboratory tests including complete blood count, serum levels of ferritin, folate, vitamin $B_{12}$, zinc, 25-hydroxyvitamin D (25(OH)D), herpes simplex virus type-l (HSVl) IgG and herpes simplex virus type-2 (HSV2) IgG were evaluated in each participant. The exclusion criteria were pregnancy, immunosuppression, malignancy, inflammatory bowel disease, diet restrictions, vitamin and mineral supplements.

Data were represented as mean \pm standard deviation or median for quantitative variables; counts and percentage for categorical variables. Differences between two groups were tested with Mann Whitney U test for continuous variables and chi-square or Fisher exact tests as appropriate for categorical variables. The data were analyzed using SPSS 20.0 Statistical Package Program.

\section{RESULTS}

The study included 20 patients (15 female, 5 male) with recurrent aphthous stomatitis and 20 healthy individuals ( 14 female, 6 male) within the control group. The mean age of the patients was $34 \pm 12.3$ (range: 18-58). The mean age of the healthy individuals was 33.9 \pm 13.4 (range: 18-60) $(\mathrm{p}=1)$. The mean disease duration was $24.6 \pm 32.9$ months (range: $1-120$ months). Three $(15 \%)$ patients had at least one first-degree family member who suffered from recurrent aphthous stomatitis.
The mean hemoglobin level of the patients and healthy individuals were $13.6 \pm 1.5 \mathrm{~g} / \mathrm{dL}$ and $14.3 \pm 1.2 \mathrm{~g} / \mathrm{dL}$, respectively $(\mathrm{p}=0.1)$ (normal range: $11.7-17 \mathrm{~g} / \mathrm{dL}$ ). Two (10\%) patients had decreased serum hemoglobin levels, while all the healthy individuals had normal serum hemoglobin levels $(p=0.4)$. The mean white blood cell count of the patients and healthy individuals were $7.3 \pm 1.610^{3} / \mu \mathrm{L}$ and $6.7 \pm 1.310^{3} / \mu \mathrm{L}$, respectively $(p=0.3)$ (normal range: $4.2-10.2103 / \mu \mathrm{L})$. All the participants had normal serum white blood cell count. The mean platelet count of the patients and healthy individuals were $255.4 \pm 68.510^{3} / \mu \mathrm{L}$ and $252.4 \pm 54.5$ $10^{3} / \mu \mathrm{L}$, respectively $(\mathrm{p}=0.7$ ) (normal range: $142-450$ $\left.10^{3} / \mu \mathrm{L}\right)$. One $(5 \%)$ patient had low platelet count, while all the healthy individuals had normal platelet counts $(\mathrm{p}=1)$. The mean platelet volume of the patients and healthy individuals were $7.888 \pm 1.4 \mathrm{fL}$ and $7.913 \pm 0.9$ $\mathrm{fL}$, respectively $(\mathrm{p}=0.7)$ (normal range: $6.4-11 \mathrm{fL}$ ). Three (15\%) patients and one $(5 \%)$ healthy individual had low mean platelet volume. Increased mean platelet volume was observed only in one $(5 \%)$ patient $(\mathrm{p}=0.3)$.

The mean serum ferritin level of the patients and healthy individuals were $26.5 \pm 25.5 \mathrm{ng} / \mathrm{mL}$ and $42 \pm 30 \mathrm{ng} / \mathrm{mL}$, respectively $(\mathrm{p}=0.04)$ (normal range: $10-204 \mathrm{ng} / \mathrm{mL}$ ). Low serum ferritin levels were observed in $6(30 \%)$ patients and $2(10 \%)$ healthy individuals $(\mathrm{p}=0.2)$ (Fig. 1). The mean serum folate level of the patients and healthy individuals were $5.7 \pm 1.8 \mu \mathrm{g} / \mathrm{L}$ and $6.6 \pm 2.2 \mu \mathrm{g} / \mathrm{L}$, respectively $(\mathrm{p}=0.1)$ (normal range: 3.1-20 $\mu \mathrm{g} / \mathrm{L}$ ). All the participants had normal serum folate levels. The mean serum vitamin $B_{12}$ level of the patients and healthy individuals were $343.7 \pm 171.9$ $\mathrm{pg} / \mathrm{mL}$ and $281.6 \pm 93.9 \mathrm{pg} / \mathrm{mL}$, respectively $(\mathrm{p}=0.2)$ (normal range: 190-880 pg/mL). Four (20\%) patients had low serum vitamin $B_{12}$ levels, while 3 (15\%) healthy individuals had low serum vitamin $B_{12}$ levels $(p=1)$. The mean serum zinc level of the patients and healthy individuals were $78.8 \pm 14.4 \mu \mathrm{g} / \mathrm{dL}$ and $85.3 \pm 15.9 \mu \mathrm{g} / \mathrm{L}$, respectively $(\mathrm{p}=0.1)$ (normal range: $60-150 \mu \mathrm{g} / \mathrm{dL}$ ). All the participants had normal serum zinc levels. The mean serum $25(\mathrm{OH}) \mathrm{D}$ level of the patients and healthy individuals were $13.6 \pm 6.5 \mathrm{ng} / \mathrm{mL}$ and $20.9 \pm 10 \mathrm{ng} / \mathrm{mL}$, respectively $(p=0.01)$ (normal range: $20-60 \mathrm{ng} / \mathrm{mL}$ ). Fourteen $(70 \%)$ patients had decreased serum $25(\mathrm{OH})$ D levels, while $9(45 \%)$ healthy individuals had decreased serum $25(\mathrm{OH})$ D levels $(\mathrm{p}=0.2)$ (Fig. 2).

The mean serum HSVl IgG level of the patients and healthy individuals were $52.6 \pm 72.4 \mathrm{RU} / \mathrm{mL}$ and $80.8 \pm 83.9 \mathrm{RU} / \mathrm{mL}$, respectively $(\mathrm{p}=0.4)$ (range: negative $<16$, positive $>22 \mathrm{RU} / \mathrm{mL}$ ). Positive serum 


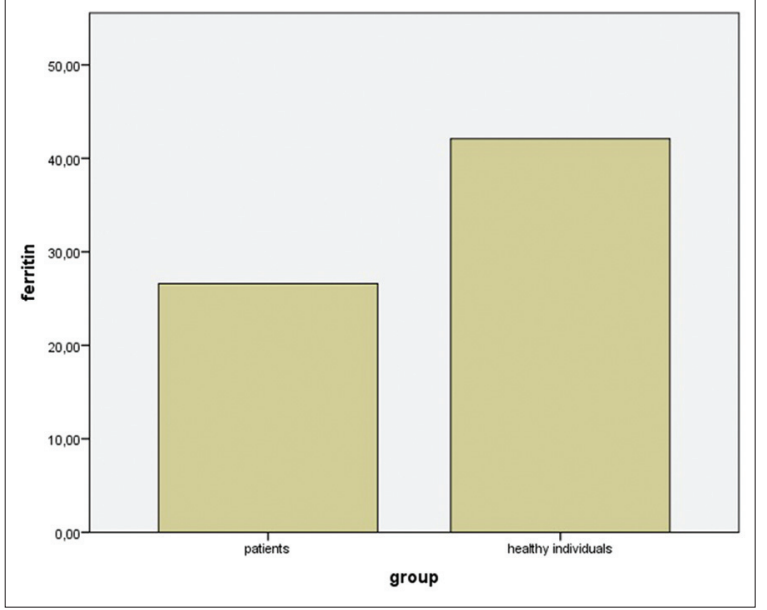

Figure 1: The mean serum ferritin level of the patients $(26.5 \pm 25.5 \mathrm{ng} / \mathrm{mL})$ was significantly lower compared to healthy individuals $(42 \pm 30 \mathrm{ng} / \mathrm{mL})$ $(p=0.04)$.

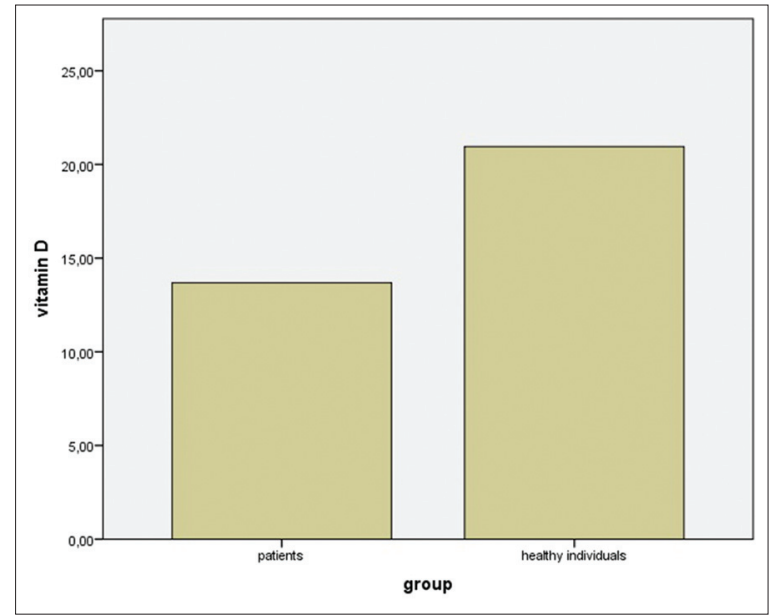

Figure 2: The mean serum 25(OH)D level of the patients $(13.6 \pm 6.5 \mathrm{ng} / \mathrm{mL})$ was significantly lower compared to healthy individuals $(20.9 \pm 10 \mathrm{ng} / \mathrm{mL})(p=0.01)$.

HSV1 IgG levels were observed in eleven (55\%) patients and in $10(50 \%)$ healthy individuals $(\mathrm{p}=1)$. The mean serum HSV2 IgG level of the patients and healthy individuals were $10.5 \pm 34.3 \mathrm{RU} / \mathrm{mL}$ and $2.6 \pm 2.9$ $\mathrm{RU} / \mathrm{mL}$, respectively $(\mathrm{p}=0.4)$ (range: negative $<16$, positive $>22 \mathrm{RU} / \mathrm{mL}$ ). Positive serum HSV2 IgG level was observed in one (5\%) patient. None of the healthy individuals had positive serum HSV2 IgG level $(\mathrm{p}=1)$.

\section{DISCUSSION}

Despite being the most common ulcerative disease of the oral mucosa, the etiology of recurrent aphthous stomatitis has not been clearly identified yet. Therefore, current treatment options are usually aim to reduce symptoms [8]. Impaired mucosal barrier function, stress, oral microbial flora including Streptococcus sanguinis and Streptococcus mitis, Helicobacter pylori infection, diet, allergies, vitamin and mineral deficiencies, hematological parameters like ferritin, hemoglobin and hematocrit have been associated with recurrent aphthous stomatitis. Moreover, high levels of erythrocyte sedimentation rate, mean platelet volume, white blood cells, neutrophils and homocysteine have been reported in patients with recurrent aphthous stomatitis [8].

Sun et al. investigated hemoglobin, iron, vitamin $\mathrm{B}_{12}$, folic acid, and homocysteine concentrations in patients with recurrent aphthous stomatitis and in healthy controls. Elevated homocysteine levels and decreased levels of hemoglobin, iron, vitamin $\mathrm{B}_{12}$ and folic acid were significantly more common in patients than in control group [9]. Compilato et al. evaluated hematological deficiencies in 32 patients with recurrent aphthous stomatitis and in 29 healthy controls. Serum iron, folic acid and vitamin $\mathrm{B}_{12}$ deficiencies were significantly more common in patient group than in healthy individuals [10]. Chen et al. reported high rates of hemoglobin, ferritin, folic acid and vitamin $\mathrm{B}_{12}$ deficiencies in patients with recurrent aphthous stomatitis [11]. Similarly, Lopez-Jornet et al. reported that iron, folic acid, and vitamin $B_{12}$ deficiencies were more frequent in patients with recurrent aphthous stomatitis compared to healthy controls [12].

Within this study, the mean serum hemoglobin level was lower in patients $(13.6 \pm 1.5 \mathrm{~g} / \mathrm{dL})$ compared to healthy individuals $(14.3 \pm 1.2 \mathrm{~g} / \mathrm{dL})$. However, no statistically significant difference has been observed in hemoglobin levels between two groups $(\mathrm{p}=0.1)$. White blood cell count, platelet count and mean platelet volume were similar in patients with recurrent aphthous stomatitis and healthy individuals within the control group. The mean serum ferritin level was significantly lower in patients $(26.5 \pm 25.5 \mathrm{ng} / \mathrm{mL})$ compared to healthy individuals $(42 \pm 30 \mathrm{ng} / \mathrm{mL})(\mathrm{p}=0.04)$. The mean serum folate level was lower in patients $(5.7 \pm 1.8 \mu \mathrm{g} / \mathrm{L})$ than in control group $(6.6 \pm 2.2 \mu \mathrm{g} / \mathrm{L})$. However, no statistically significant difference has been observed in folate levels between two groups $(p=0.1)$. In contrast, mean serum vitamin $B_{12}$ levels were higher in patients (343.7 \pm 171.9 $\mathrm{pg} / \mathrm{mL}$ ) compared to healthy individuals $(281.6 \pm 93.9$ $\mathrm{pg} / \mathrm{mL}$ ). However, no statistically significant difference has been observed in vitamin $B_{12}$ levels between two groups $(p=0.2)$.

Association between serum zinc concentration and recurrent aphthous stomatitis remains controversial. 
Ślebioda et al. detected no significant difference in serum zinc levels between patients with recurrent aphthous stomatitis and healthy controls, while Ozler reported a distinct association between zinc deficiency and recurrent aphthous stomatitis $[13,14]$.

Within this study, serum zinc levels of the participants were all in normal limits. Patients with recurrent aphthous stomatitis had lower serum zinc levels $(78.8 \pm 14.4 \mu \mathrm{g} / \mathrm{dL})$ compared to healthy individuals $(85.3 \pm 15.9 \mu \mathrm{g} / \mathrm{L})$. However, no statistically significant difference has been observed in zinc levels between two groups $(\mathrm{p}=0.1)$.

Low serum vitamin D level has been implicated as a facilitating factor in the development of recurrent aphthous stomatitis. Oztekin et al. reported significantly lower serum vitamin D levels in patients with recurrent aphthous stomatitis compared to healthy individuals [15]. In contrast, Krawiecka et al. reported similar serum vitamin D levels in patients with recurrent aphthous stomatitis and healthy controls [16].

Within this study, the mean serum 25(OH)D level was significantly lower in patients $(13.6 \pm 6.5 \mathrm{ng} / \mathrm{mL})$ than in control group $(20.9 \pm 10 \mathrm{ng} / \mathrm{mL})(\mathrm{p}=0.01)$. Vitamin $\mathrm{D}$ deficiency was detected in $70 \%$ of the patients with recurrent aphthous stomatitis.

It has been suggested that the human herpesviruses (HHVs) may play role in the development of recurrent aphthous stomatitis. However, Brice et al. examined the members of the HHV family including HSVl, HSV2, varicella zoster virus, Epstein-Barr virus, cytomegalovirus, HHV-6, HHV-7 and HHV-8, in the oral mucosa of patients with recurrent aphthous stomatitis and control subjects. The frequency of detection of HHV DNA was not greater in the mucosa of patients than in controls [17]. In addition, Seoudi et al. reported no significant difference between HSVI IgG and HSV2 $\mathrm{IgG}$ levels in patients with Behçet's disease, recurrent aphthous stomatitis and healthy controls [18].

Within this study, a positive HSVl IgG result was detected in $55 \%$ of the patients with recurrent aphthous stomatitis and in $50 \%$ of healthy individuals, whereas only one patient was HSV2 IgG positive. The results indicate no correlation between HSV and recurrent aphthous stomatitis.

In conclusion, this study revealed no association between recurrent aphthous stomatitis and mean platelet volume, white blood cell count, HSV1, HSV2, serum levels of hemoglobin, folate, vitamin $B_{12}$ and zinc. However, decreased serum levels of ferritin and $25(\mathrm{OH}) \mathrm{D}$ were more prevalent in patients with recurrent aphthous stomatitis compared to healthy individuals. Therefore, we suggest that serum ferritin and $25(\mathrm{OH}) \mathrm{D}$ levels should be evaluated in all patients with recurrent aphthous stomatitis. Replacement therapies may be helpful in the management of the disease in cases with iron or vitamin D deficiency.

\section{Statement of Human and Animal Rights}

All procedures followed were in accordance with the ethical standards of the responsible committee on human experimentation (institutional and national) and with the Helsinki Declaration of 1975, as revised in 2008 .

\section{Statement of Informed Consent}

Informed consent was obtained from all patients for being included in the study.

\section{REFERENCES}

1. Mortazavi H, Safi Y, Baharvand M, Rahmani S. Diagnostic features of common oral ulcerative lesions: an updated decision tree. Int J Dent. 2016;2016:7278925.

2. Akintoye SO, Greenberg MS. Recurrent aphthous stomatitis. Dent Clin North Am. 2014;58:281-97.

3. Brzeziński P, Wollina U, Espinoza-Benavides L, Chang P, Mohamed M, Geller SA. Dermatology eponyms-sign-lexicon (S). Part II. Our Dermatol Online. 2018;9:470-7.

4. Cui RZ, Bruce AJ, Rogers RS $3^{\text {rd }}$. Recurrent aphthous stomatitis. Clin Dermatol. 2016;34:475-81.

5. Queiroz SIML, Silva MVAD, Medeiros AMC, Oliveira PT, Gurgel BCV, Silveira ÉJDD. Recurrent aphthous ulceration: an epidemiological study of etiological factors, treatment and differential diagnosis. An Bras Dermatol. 2018;93:341-6.

6. Edgar NR, Saleh D, Miller RA. Recurrent aphthous stomatitis: a review. J Clin Aesthet Dermatol. 2017;10:26-36.

7. Woo SB, Sonis ST. Recurrent aphthous ulcers: a review of diagnosis and treatment. J Am Dent Assoc. 1996;127:1202-13.

8. Saikaly SK, Saikaly TS, Saikaly LE. Recurrent aphthous ulceration: a review of potential causes and novel treatments. J Dermatolog Treat. 2018;29:542-52.

9. Sun A, Chen HM, Cheng SJ, Wang YP, Chang JY, Wu YC, et al. Significant association of deficiencies of hemoglobin, iron, vitamin B12, and folic acid and high homocysteine level with recurrent aphthous stomatitis. J Oral Pathol Med. 2015;44:300-5.

10. Compilato D, Carroccio A, Calvino F, Di Fede G, Campisi G. Haematological deficiencies in patients with recurrent aphthosis. J Eur Acad Dermatol Venereol. 2010;24:667-73.

11. Chen H, Sui Q, Chen Y, Ge L, Lin M. Impact of haematologic deficiencies on recurrent aphthous ulceration: a meta-analysis. $\mathrm{Br}$ Dent J. 2015;218:E8.

12. Lopez-Jornet P, Camacho-Alonso F, Martos N. Hematological study of patients with aphthous stomatitis. Int J Dermatol. 2014;53:159-63. 


\section{www.odermatol.com}

13. Ślebioda Z, Krawiecka E, Szponar E, Dorocka-Bobkowska B. Evaluation of serum zinc levels in patients with recurrent aphthous stomatitis (RAS). BMC Oral Health. 2017;17:158.

14. Ozler GS. Zinc deficiency in patients with recurrent aphthous stomatitis: a pilot study. J Laryngol Otol. 2014;128:531-3.

15. Öztekin A, Öztekin C. Vitamin D levels in patients with recurrent aphthous stomatitis. BMC Oral Health. 2018;18:186.

16. Krawiecka E, Ślebioda Z, Szponar E, Kowalska A, DorockaBobkowska B. Vitamin D status in recurrent aphthous stomatitis. Postepy Dermatol Alergol. 2017;34:612-7.

17. Brice SL, Cook D, Leahy M, Huff JC, Weston WL. Examination of the oral mucosa and peripheral blood cells of patients with recurrent aphthous ulceration for human herpesvirus
DNA. Oral Surg Oral Med Oral Pathol Oral Radiol Endod. 2000;89:193-8.

18. Seoudi N, Bergmeier LA, Hagi-Pavli E, Bibby D, Fortune F. The seroprevalence and salivary shedding of herpesviruses in Behçet's syndrome and recurrent aphthous stomatitis. J Oral Microbiol. 2015;7:27156.

Copyright by Funda Tamer, et al. This is an open access article distributed under the terms of the Creative Commons Attribution License, which permits unrestricted use, distribution, and reproduction in any medium, provided the original author and source are credited.

Source of Support: Nil, Conflict of Interest: None declared. 